\title{
A CONCESSÃO DE LICENÇA PARA MOTOTAXISTAS COM ANTECEDENTES CRIMINAIS - UM CONFLITO DE DIREITOS FUNDAMENTAIS
}

\section{ESTUDO DE CASO}

ARAUJO, Renata Gomes De ${ }^{1}$

ARAUJO, Renata Gomes De. A concessão de licença para mototaxistas com antecedentes criminais - Um conflito de Direitos Fundamentais. Revista Científica Multidisciplinar Núcleo do Conhecimento. Ano 05, Ed. 03, Vol. 08, pp. 14-30. Março de 2020. ISSN: 2448-0959, Link de acesso: https://www.nucleodoconhecimento.com.br/lei/concessao-de-licenca

\section{RESUMO}

Este artigo se propõe a discutir sobre a temática da concessão da licença para motoristas que possuem antecedentes criminais. A fim de ilustrar o problema aqui elencado que é a dificuldade de reinserção desses indivíduos no meio laboral, a pesquisa propõe, como metodologia, a perspectiva qualitativa, apoiando-se, para tanto, no estudo de caso. A partir da consulta à literatura relacionada, tem-se como objetivo analisar os argumentos favoráveis e desfavoráveis à reintegração desses sujeitos no meio laboral após cumprida a pena. Para a análise do caso concreto, o trabalho se apoiou em princípios e entendimentos de caráter doutrinário e jurisprudencial para refletir sobre como o Supremo Tribunal de Justiça do estado de São Paulo, mais especificamente da cidade de São José do Rio Preto, não autorizou a liberação de tal concessão.

Palavras-chave: Concessão de licença para mototaxistas, conflito entre princípios, dignidade da pessoa humana.

\footnotetext{
${ }^{1}$ Advogada. Pós graduada em Direito Público pela PUC.
} 


\section{INTRODUÇÃO}

Este trabalho propõe o estudo de um caso concreto à luz da Constituição Federal e dos princípios gerais que regem o Estado Democrático de Direito. A temática envolve o importante conflito de princípios constitucionais fundamentais, pois, de um lado, a dignidade da pessoa humana, a valorização da dimensão social do trabalho e a erradicação da marginalização se constituem como fundamentos e objetivos da República Federativa do Brasil, e, por outro lado, há a supremacia do interesse público sobre o privado, a segurança pública e a legalidade.

Ademais, pretende-se averiguar se o entendimento prevalecente no Superior Tribunal de Justiça nos dias atuais coaduna com os preceitos da Constituição da República de 1988. Traz-se à baila o acordão proferido pelo Superior Tribunal de Justiça no Agravo em Recurso Especial número 495.725 - SP (2014/0066962-4), de relatoria do Ministro Napoleão Nunes Maia Filho, julgado em 23 de março de 2018. Será inicialmente exposto o caso a que se refere, seguindo-se das análises doutrinarias e jurisprudências e de breves comentários.

\section{APRESENTAÇÃO DO CASO}

O presente caso concreto trata-se de um Agravo em Recurso Especial cujo agravante é o Município de São José do Rio Preto e o agravado é o Senhor Rodrigo Botazzo Santana. Para melhor entendimento, há de se contextualizar a situação. O senhor Rodrigo impetrou um mandado de segurança com medida liminar, no ano de 2010, contra ato do secretário de trânsito e transportes de São José do Rio Preto, requerendo licença para atuar como mototaxista. Tal licença foi negada com a justificativa de que o impetrante desde 1999 respondia a processos criminais decorrentes do delito de furto e encontrava-se em gozo do sursis. A negativa da

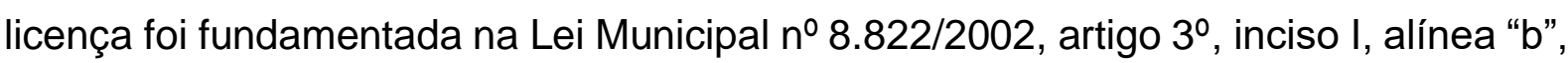
que veda a concessão da licença para exercício da profissão de mototaxista a reincidentes em crime de furto, como se verifica abaixo: 
Art. 3ำ Para a prestação do serviço, deverão ser preenchidos os requisitos e condições seguintes:

I - em relação ao autorizatário:

b) não ser reincidente em crimes de furto e sobre entorpecentes, sem prejuízo do que estabelece o artigo 329 da Lei Federal ํㅜ 503, de 23 de setembro de 1997, que instituiu o Código de Trânsito Brasileiro, bem como, comprovando que do término do cumprimento da pena já tenha decorrido ais de um ano (Lei oㅜ 10.835/2010).

Requereu então o Sr. Rodrigo, via Mandado de Segurança, a concessão de medida liminar para determinar à autoridade coatora que emitisse o documento necessário para o registro e licença para o exercício da função de mototaxista, assegurando o direito do impetrante de exercer tal atividade e, ao final, requereu o julgamento de procedência do writ, confirmando os efeitos da liminar concedida. No julgamento do MS pela juíza de primeiro grau, Tatiana Pereira Viana Santos, o Secretário de Trânsito e Transporte de São José do Rio Preto e o Município de São José do Rio Preto prestaram depoimentos sustentando que a Lei ํㅗ 8.822/2002 era constitucional e encontrava-se em acordo com o exercício da competência municipal de disciplinar matérias afetas ao interesse local, de modo que as exigências do município para a concessão da licença se mostravam razoáveis e proporcionais à proteção da população e dos usuários dos serviços de mototáxi.

O Ministério Público manifestou-se pela denegação da segurança. Concluiu a juíza pela denegação de seguimento ao mandado de segurança, com a justificativa de que além da Lei municipal acima citada, a Lei Federal 12.009/2009 é ainda mais severa ao exigir, em seu artigo $2^{\circ}$, parágrafo único, inciso $\mathrm{V}$, a emissão de certidão negativa das varas criminais. Frisou a magistrada sobre a importância da Supremacia do Interesse Público sobre o Privado, enfatizando o poder do município de atuar na atividade de transporte urbano almejando controlar a idoneidade dos prestadores do serviço e a segurança pública. Nesse sentido, segue conteúdo do julgado: 
Destaque-se que o exercício de qualquer trabalho é livre, mas observadas as disposições legais (artigo 5을 inciso XIII, da Constituição Federal) e no caso a Lei municipal dispôs como condição para a concessão de alvará para o exercício da atividade de mototaxista a ausência de antecedentes criminais relativos aos crimes de furto e relacionados a entorpecentes, bem como a não reincidência em crime culposo por acidente de trânsito, ao passo que a Lei Federal № 12.009/2009 que regulamenta a matéria é ainda mais severa ao prever como condição para o exercício da profissão de mototaxista, a existência de certidões criminais negativas. No presente caso, o impetrante é reincidente específico em relação ao crime de furto, ostentando quatro condenações pela prática deste delito (fls. 81/82), a última com término de pena previsto para 2012 e não se vislumbra na regulamentação legal municipal do exercício da profissão a inconstitucionalidade invocada, diante das circunstâncias específicas do caso e do poder do Município de regulamentar atividade de transporte urbano e da prevalência do interesse público e preocupação municipal para almejar garantir a idoneidade dos prestadores de serviço (DIÁRIO DE JUSTIÇA DO ESTADO DE SÃO PAULO, 2011, p. 1375).

\subsection{SOLUÇÃO DADA PELO TRIBUNAL}

Diante da sentença desfavorável, o Senhor Rodrigo apelou da decisão no Tribunal de Justiça de São Paulo, que reformou a decisão dada em sentença de primeiro grau. Entendeu o Tribunal que não se pode negar que a norma constante do artigo 5o, inciso XIII da Constituição Federal, que estabelece o livre exercício de qualquer profissão desde que atendidas as qualificações que a lei determinar, apesar de ser constitucional e de fundamentar a Lei Federal n 12.009, de 29 de julho de 2009 e a Lei Municipal n $8.802 / 02$, não pode ser interpretada isoladamente, mas dentro de um sistema que prestigie os direitos fundamentais e de forma que haja uma ponderação, caso haja conflito entre esses direitos. O texto constitucional há de ser interpretado de 
maneira sistemática, na perspectiva de se superar aparente conflito normativo entre a regra do artigo 5º, XIII, da Constituição Federal.

Esta garante a execução de qualquer trabalho, ofício ou profissão, ressalvadas as peculiaridades legais, a norma de eficácia plena e valores como a Dignidade da Pessoa Humana, a Valorização Social do Trabalho, a Construção de uma sociedade livre, justa e solidária e a erradicação da marginalização. São fundamentos e objetivos da República. É bem verdade que a Lei Federal 12.009/2009 e a Lei municipal 8.822/2002 são constitucionais e fundamentam o princípio da Legalidade à medida em que, conforme autorizado pela própria constituição, o exercício de profissão, ofício ou trabalho não é ilimitado, podendo sofrer limitações convenientes e proporcionais por leis específicas.

No caso, ainda se presa pela segurança pública e organização do próprio município, com base na Soberania do Interesse Público sobre o Privado. Entretanto, esses valores se chocam com outros valores fundamentais e de acordo com o entendimento do Tribunal, com os mais importantes, como a Dignidade da Pessoa Humana e a Valorização do Trabalho. O Tribunal trouxe à baila a discussão acerca da dignidade do requerente da licença, que está tentando se inserir novamente na sociedade, isto é, buscar uma nova chance. Nesta toada, entendeu o TJSP que:

O mesmo Estado que exige comprovação de trabalho para a concessão de regime aberto (art. 114, I, da Lei Federal no 7.210/84) e do livramento condicional (art. 132, § 1ํㅡ, b, da Lei no 7.210/84), não pode dar as costas para o egresso quando ele necessita de uma oportunidade para exercer atividade lícita.

O relator trouxe, ainda, referência a outro julgado sobre o mesmo assunto em que se esclarece que é incompatível admitir para a profissão de mototaxista as mesmas exigências quanto à vida pregressa que se exige nas carreiras públicas. Nesse sentido: 
Pretender que um taxista tenha vida pregressa como se fosse atuar na vida pública, em cargo de confiança, lidando com questões de alta responsabilidade, é exigir demais. Torna-se regra abusiva, que cerceia o direito ao trabalho.

Dessa forma, no acórdão de apelação, declarou o Tribunal que o indeferimento de licença para exercer a função de mototaxista a um portador de antecedentes significa criar um óbice de conteúdo marcadamente preconceituoso que não se coaduna com um Estado que tem o dever de garantir a dignidade humana, o valor social do trabalho e, ainda, acrescenta à pena que está sendo cumprida pelo autor, uma sanção de natureza civil que não é autorizada pela Lei. Terminou a fundamentação, ainda, afirmando que a tese alegada em sentença de primeiro grau, de que caberia, ao Poder Público assegurar, aos municípios, a segurança na prestação do serviço de transporte de passageiros, regulamentando a atividade e impondo condições para a concessão de licença não vinga, isto porque o princípio da supremacia do interesse público sobre o particular precisa de ser interpretado à luz do princípio da dignidade da pessoa humana. Nesse sentido, julgou procedente o recurso e reformou a sentença.

\section{LEGISLAÇÃO APLICÁVEL AO CASO}

O Município de São José do Rio Preto entrou com Recurso Especial com fundamento no artigo 105, III, a da Constituição, o qual foi inadmitido. E, finalmente, ingressou com Agravo em Recurso Especial da decisão que inadmitiu o Recurso Especial, o qual o julgamento é objeto central de análise neste trabalho. Segue ementa do referido julgado no Superior Tribunal de Justiça:

AGRAVO EM RECURSO ESPECIAL № 495.725 - SP (2014/0066962-

4) RELATOR : MINISTRO NAPOLEÃO NUNES MAIA FILHO AGRAVANTE : MUNICÍPIO DE SÃO JOSÉ DO RIO PRETO PROCURADORES : WALTER MARTINS FILHO E OUTRO (S) SP143160 RONALDO BITENCOURT DUTRA - SP227059 AGRAVADO : RODRIGO BOTAZZO SANTANA ADVOGADOS : MOACIR VENANCIO DA SILVA JUNIOR E OUTRO (S) - SP197141 CÁSSIA 
PRISCILA BANHATO - SP264425 DECISÃO PROCESSUAL CIVIL E ADMINISTRATIVO. AGRAVO EM RECURSO ESPECIAL. MANDADO DE SEGURANÇA. ATOS ADMINISTRATIVOS. LICENÇA PARA O EXERCÍCIO DA ATIVIDADE DE MOTOTAXISTA. TEMA APRECIADO SOB O ENFOQUE EXCLUSIVAMENTE CONSTITUCIONAL. ARTS. 5․, XIII, 1ํ, III E IV, 3으, I E III, DA CF/1988. PRINCÍPIOS DA SUPREMACIA DO INTERESSE PÚBLICO SOBRE O PARTICULAR E DA DIGNIDADE HUMANA. INVIABILIDADE DE APRECIAÇÃO EM RECURSO ESPECIAL. AGRAVO DO MUNICÍPIO DE SÃO JOSÉ DO RIO PRETO A QUE SE NEGA PROVIMENTO.

1. Agrava-se de decisão que inadmitiu Recurso Especial interposto pelo MUNICÍPIO DE SÃO JOSÉ DO RIO PRETO com fundamento no art. 105, III, a da Constituição Federal, contra acórdão proferido pelo Tribunal de Justiça do Estado de São Paulo, assim ementado: MANDADO DE SEGURANÇA - Pedido de licença para o exercício da atividade de mototaxista - Lei Municipal 8.802/02, que estabelece como condição para a prestação do serviço de mototáxi a inexistência de antecedentes criminais por parte do permissionário - Consideração dos princípios constitucionais da dignidade da pessoa humana, da valorização da dimensão social do trabalho e da construção de uma sociedade justa e solidária em nome dos quais se há de conceder oportunidade de trabalho à pessoa condenada criminalmente - Princípio da supremacia do interesse público sobre o particular interpretado à luz do princípio da dignidade humana - Recurso provido (fls. 171).

2. Nas razões do Recurso Especial inadmitido, a parte recorrente alega ofensa ao artigo $2^{\circ}$, parág. único, $\mathrm{V}$ da Lei 12.009/2009 ao argumento de que 0 ato de indeferimento do alvará para o exercício de atividade de mototaxista foi praticado em 
observância à legislação que exige a apresentação de certidões negativas das varas criminais.

3. É o relatório do essencial.

4. Na hipótese dos autos, o Tribunal de origem consignou: A norma do artigo 5ํ, XIII, da Constituição Federal, estabelece o livre exercício de qualquer profissão, desde que atendidas as qualificações que a lei determinar. Neste sentido, a Lei Federal 12.009, de 29 de julho de 2009, ao regulamentar o exercício das atividades dos profissionais em transporte de passageiros, dispõe, no artigo $2^{\circ}$, parágrafo único, $\mathrm{V}$, que a permissão para o exercício da atividade de mototaxista está condicionada à apresentação de certidões criminais negativas. No âmbito municipal, foi editada a Lei 8.802/2002, que, em acordo com a norma federal, estabelece como condição para a prestação do serviço de mototáxi a inexistência de antecedentes criminais, por parte do permissionário, relativos a crimes de furto e àqueles relacionados a entorpecentes, exigindo também que o candidato não seja reincidente em crime culposo por acidente de trânsito. Mas o texto constitucional há de ser interpretado de maneira sistemática, na perspectiva de se superar aparente conflito normativo entre a regra do artigo $5^{\circ}, \mathrm{XIII}$, norma de eficácia plena, e aquela dos artigos 1ำ, III e IV, $3^{\circ}$, I e III, todos da Constituição Federal. Decerto, se o respeito à dignidade da pessoa humana, a valorização da dimensão social do trabalho, a construção de uma sociedade justa e solidária, com erradicação da marginalização, são fundamentos do Estado Democrático de Direito, claro está que não se pode negar àquele que se viu condenado criminalmente oportunidade de trabalho, que é pressuposto da ressocialização. (...). E a tese de que caberia ao Poder Público assegurar aos munícipes a segurança na prestação do serviço de transporte de passageiros, regulamentando a atividade $\mathrm{e}$ impondo condições para a concessão de licença, não vinga, pois 
o princípio da supremacia do interesse público sobre o particular há de ser interpretado à luz do princípio da dignidade humana (fls. 172/175).

5. Verifica-se que a questão em discussão foi dirimida pela Corte de origem com base na interpretação dos arts. $5^{\circ}$, XIII, 1을 III e IV, $3^{\circ}$, I e III, da CF/1988 e dos princípios da supremacia do interesse público sobre o particular e da dignidade humana, adotando fundamentação exclusivamente constitucional, motivo pelo qual é inviável a alteração do decisum em Recurso Especial, sob pena de usurpação da competência da Suprema Corte.

6. Ante o exposto, nega-se provimento ao Agravo do MUNICÍPIO DE SÃO JOSÉ DO RIO PRETO.

7. $\mathrm{n}$

8. Intimações necessárias.

Brasília (DF), 23 de março de 2018.

NAPOLEÃO NUNES MAIA FILHO MINISTRO RELATOR

(STJ - AREsp: 495725 SP 2014/0066962-4, Relator: Ministro NAPOLEÃO NUNES MAIA FILHO, Data de Publicação: DJ $11 / 04 / 2018)$

Conforme a ementa, nota-se que o STJ reproduziu praticamente o inteiro teor do acórdão proferido em sede de apelação e negou provimento ao Recurso Especial, mantendo a decisão do Tribunal de origem.

\section{ANÁLISE DE DECISÕES DIVERGENTES}

No caso exposto, há o claro conflito de princípios fundamentais e constitucionais. De um lado, encontra-se o princípio da Legalidade (princípio previsto no artigo 5oㅡ. II da Constituição Federal), a supremacia do interesse público (princípio implícito basilar da Administração Pública) e valores como a segurança pública e a autonomia do Estado. 
E, de outro, há princípios como a dignidade da pessoa humana, valorização social do trabalho, construção de uma sociedade livre, justa e solidária e, ainda, erradicação da pobreza e marginalização. Esses últimos valores integram os fundamentos e objetivos da República Federativa do Brasil, conforme previsão expressa nos artigos 1ำ, incisos III e IV e 3ํ, incisos I e III da Constituição Federal. A legalidade se traduz à medida em que há duas leis vigentes e constitucionais que poderiam ser aplicadas ao caso concreto (Lei Federal 12.009/2009 e Lei do município de São José do Rio Preto $8.822 / 2002)$.

Estão em perfeita consonância com 0 artigo 5ํ, XIII da Constituição Federal, que preconiza que "é livre o exercício de qualquer trabalho, ofício ou profissão, atendidas as qualificações profissionais que a lei estabelecer". Dessa forma, nas palavras de Novelino (2010), o princípio da legalidade é o postulado dos Estados de direito. A rigor, é dele que decorre a própria qualificação de um Estado como 'de direito': todos, sem exceção, estão sujeitos ao império da lei; ninguém - nem mesmo os particulares, nem os agentes públicos - pode agir de modo a contrariar o ordenamento jurídico. Desta forma, a legalidade prevista no artigo $5^{\circ}$, inciso II, que não se confunde com a legalidade administrativa prevista no artigo 37 , ambos da constituição, prevê que 'ninguém' será obrigado a fazer ou deixar de fazer alguma coisa senão em virtude de lei.

Seguindo nesta esteira, poderia-se concluir que, havendo lei e esta sendo constitucional, deveria ser cumprida impreterivelmente. Entretanto, com o advento do Neoconstitucionalismo e do Estado Democrático de direito, não se pode mais falar em lógica do tudo ou nada. Deve sempre haver ponderação quando direitos fundamentais entrarem em conflito, observando-se as peculiaridades de cada caso concreto. $O$ princípio da Supremacia do Interesse Público sobre o Privado, também citado no julgado em estudo, é um princípio implícito e coronário da Administração Pública. De acordo com esse princípio, existindo conflito entre o interesse público e o interesse particular, deverá prevalecer o primeiro. Trazendo este princípio para o caso concreto estudado, o interesse público da administração municipal poderia se sobrepor ao 
interesse privado do requerente da licença para mototaxista com antecedentes criminais.

Na mesma linha, alega-se a segurança pública e a autonomia do município em executar as suas próprias leis e procedimentos. Entretanto, apesar dos argumentos serem razoáveis, os princípios se chocam com outros e com valores de inquestionável importância e fundamentais como a dignidade da pessoa humana, valorização social do trabalho, construção de uma sociedade livre, justa e solidária e a erradicação da pobreza e marginalização com o objetivo de diminuir as desigualdades sociais. A dignidade da pessoa humana é um fundamento da República Federativa do Brasil, prevista no artigo 1ํ, inciso III da Constituição Federal. Para muitos doutrinadores, é o princípio mais importante do ordenamento jurídico e, segundo Lenza (2011), pode ser bem definido como o núcleo essencial do constitucionalismo moderno. Assim, diante de colisões, a dignidade servirá para orientar as necessárias soluções de conflitos". Sarlet (2012) traz um conceito de Dignidade da Pessoa Humana, qual seja:

Temos por dignidade da pessoa humana a qualidade intrínseca e distintiva de cada ser humano que o faz merecedor do mesmo respeito e consideração por parte do Estado e da comunidade, implicando, neste sentido, um complexo de direitos e deveres fundamentais que assegurem a pessoa tanto contra todo e qualquer ato de cunho degradante e desumano, como venham a the garantir as condições existenciais mínimas para uma vida saudável, além de propiciar e promover sua participação ativa co-responsável nos destinos da própria existência e da vida em comunhão dos demais seres humanos (SARLET, 2001, p. 60).

O Supremo Tribunal Federal também já se manifestou acerca do assunto e definiu a Dignidade como:

(...) o postulado da dignidade da pessoa humana, que representa considerada a centralidade desse princípio essencial (CF, art. 1ํ, III) significativo vetor interpretativo, verdadeiro valor-fonte que conforma e 
inspira todo o ordenamento constitucional vigente em nosso País e que traduz, de modo expressivo, um dos fundamentos em que se assenta, entre nós, a ordem republicana e democrática consagrada pelo sistema de direito constitucional positivo (...). (HC 95464, Relator: Min. CELSO DE MELLO, Segunda Turma, julgado em 03/02/2009, DJe-048 DIVULG 12-03-2009 PUBLIC 13-03-2009 EMENT VOL-02352-03 PP-00466).

Como visto, a dignidade da pessoa humana deve ser interpretada como princípio fundamental do ordenamento jurídico pátrio, isto é, como o mínimo de direitos que garantem uma existência digna. É um norte constitucional que deve ser respeitado com máximo afinco. Trazendo a dignidade para o caso objeto de estudo, nota-se que os tribunais ao fazerem a ponderação entre os princípios em conflito, no caso concreto, penderam para o lado da Dignidade. A fundamentação integral do julgado foi pautada neste princípio, como se nota em vários trechos citados e na ementa destacada. A negativa de licença para exercício da profissão de mototaxista, fere, indubitavelmente, a dignidade humana do requerente, uma vez que já o coloca como "mau elemento" e o impossibilita de mudar a sua situação e se reintegrar na sociedade.

E, como bem colocado no julgado, não é coerente que o mesmo Estado que cobra a recolocação do indivíduo da sociedade negue a sua licença para reinserção no mercado de trabalho. Na mesma linha da dignidade, outro princípio trazido pelos tribunais foi a Valorização Social do Trabalho, também fundamento da República, expresso no artigo 1ํㅡㄹ inciso IV da Constituição Federal. Conforme Lenza (2011), a ordem econômica tem como objetivo assegurar a todos existência digna, conforme os ditames da justiça social, e, assim, funde-se em dois grandes pilares: a valorização do trabalho humano e a livre iniciativa. Dessa maneira, o constituinte, além de privilegiar o modelo capitalista, estabelece, como finalidade da ordem econômica, assegurar a todos a existência digna, conforme os ditames da justiça social, afastando-se, assim, de um Estado absenteísta nos moldes do liberalismo.

Neste raciocínio, reforça-se o entendimento dos tribunais no sentido de conceder a licença para que o requerente, apesar de condenação, possa ter uma nova chance de 
recomeço, recolocando-se no mercado de trabalho, e, dessa forma, buscando uma vida digna. É trazido à baila, também, nos acórdãos, os objetivos da República Federativa do Brasil, previstos expressamente no artigo $3^{\circ}$, incisos I e II da Constituição Federal, quais sejam: a construção de uma sociedade livre, justa e solidária e a erradicação da pobreza e da marginalização e a redução das desigualdades sociais e regionais. Todos os objetivos encontram guarida na dignidade da pessoa humana, princípio basilar e fundamentam o caso concreto, na medida em que a possibilidade de um emprego digno para o requerente contribui para 0 cumprimento de tais objetivos.

\section{AÇÃO CIVIL PÚBLICA PARA TUTELA DESSES INTERESSES}

O tema é bastante polêmico na jurisprudência, havendo, no âmbito dos tribunais locais, julgados que vão para os dois lados, como será demonstrado a seguir.

AGRAVO REGIMENTAL - MANDADO DE SEGURANÇA - APELAÇÃO CÍVIL - DESPROVIMENTO - ATIVIDADE DE MOTO-TAXISTA RENOVAÇÃO DA CONCESSÃO DE ALVARÁ PARA O EXERCÍCIO DA PROFISSÃO - NEGATIVA DO PODER MUNICIPAL - CERTIDÃO CRIMINAL - PROCESSO CRIMINAL - SURSIS - PRINCÍPIO CONSTITUCIONAL DA PRESUNÇÃO DA INOCÊNCIA ARBITRARIEDADE CONFIGURADA - INGERÊNCIA - INOCORRÊNCIA - RECURSO DESPROVIDO -

1 “[...] $\mathrm{O}$ ato perpetrado pelo poder público municipal, ao exigir a Certidão Negativa de antecedentes criminais para renovação do alvará de permissão para o exercício da atividade de mototaxista, além do princípio da presunção da inocência, também viola o princípio do livre exercício da profissão estabelecido no artigo $5^{\circ}$, XIII da CF" (Apelação/Reexame Necessário 56193/2014, DESA. MARIA APARECIDA RIBEIRO, TERCEIRA CÂMARA CIVIL, Julgado em 08/09/2015, Publicado no DJE 17/09/2015)". 
(TJ-MT - AGR: 01556348420158110000 155634/2015, Relator: DESA. MARIA EROSTIDES KNEIP BARANJAL, Data de Julgamento: 01/12/2015, TERCEIRA CÂMARA CIVIL, Data de Publicação: $15 / 12 / 2015)$.

A jurisprudência do TJMT está de acordo com o julgamento proferido pelo STJ e pelo TJSP no julgado em comento, no sentido em que, ao ponderar os direitos constitucionais, acabaram optando pela concessão da licença em prol da dignidade da pessoa humana e da presunção da inocência. Entretanto, há julgados em que esta tese não se sustenta, como é o caso do julgado do TJMG a seguir:

APELAÇÃO CIVIL - MANDADO DE SEGURANÇA - INDEFERIMENTO DA INICIAL - AUSÊNCIA DE DIREITO LÍQUIDO E CERTO DESCABIMENTO - ANÁLISE DO MÉRITO - APLICAÇÃO DO ART. 1.013, PARÁGRAFO 3o DO CPC/2015 - RENOVAÇÃO DE CREDENCIAL DE MOTO TAXI - CERTIDÃO NEGATIVA DE DISTRIBUIÇÃO DE AÇÕES CRIMINAIS - EXIGÊNCIA - ATO DISCRICIONÁRIO - RAZOABILIDADE - INTERESSE PÚBLICO AUSÊNCIA DE PREENCHIMENTO DOS REQUISITOS LEGAIS ORDEM DENEGADA.

1. É indevido o indeferimento da inicial do mandado de segurança por ausência de direito líquido e certo, quando a análise adentra no mérito da impetração. No entanto, encontrando-se o processo em condições de imediato julgamento, notadamente por já ter a autoridade coautora apresentado informações, deve o tribunal decidir o mérito desde logo, nos termos do art. 1.013, parágrafo 3 do $\mathrm{CPC} / 2015$.

2. $\mathrm{O}$ ato de credenciamento de mototaxistas é discricionário, cabendo, à Administração dispor sobre as exigências que entender convenientes e necessárias à adequada prestação deste serviço de natureza pública. 
3. Existência de certidão positiva de antecedentes criminais perante o Juízo Criminal da Comarca de Uberaba pela suposta prática do crime previsto no art. 129 do CP. Inobservância da Lei Municipal $11.162 / 2011$.

4. Ausência de violação ao princípio da presunção da inocência, vez que a exigência de idoneidade moral é requisito a todos aqueles que estão vinculados à Administração Pública.

5. Recurso a que se nega provimento.

(TJ-MG - AC: 10000170535058001 MG, Relator: Áurea Brasil, Data de Julgamento: 14/11/2017, Câmaras Cíveis / 5a CÂMARA CíVEL, Data de Publicação: 24/11/2017).

Como se nota no julgado, o TJMG entende que não há violação ao princípio da presunção da inocência, uma vez que a exigência da idoneidade moral é requisito a todos aqueles que estão vinculados à Administração Pública, já que, para o Tribunal, o serviço prestado por mototaxistas possui natureza pública. Diante de tamanha e inquestionável divergência, há de se citar a Ação Civil Pública, número 002246138.2010.8.26.0576, proposta pela Defensoria Pública do Estado de São Paulo contra o Município de São José do Rio Preto, insurgindo-se contra o impedimento de mototaxistas ao trabalho, pois o município regulamentou a profissão na cidade, o que afrontaria a Constituição Federal no que tange à liberdade de exercício do trabalho. Pediu a Defensoria que o município concedesse alvarás de atividade de mototaxista aos possíveis requerentes, ainda que estes ostentassem antecedentes criminais, impondo-se multa diária em razão do descumprimento de tal determinação.

A municipalidade, em resposta, apresentou contestação rebatendo os termos da inicial e pedindo a improcedência do pleito. $O$ juiz então decidiu em sentença de primeiro grau que, ao município, é dada a prerrogativa de disciplinar o exercício da profissão de mototaxista e que a Constituição Federal, no artigo 22, inciso XI, prevê a liberdade no exercício de qualquer trabalho, o que encerra a norma de eficácia contida, disciplinável e infraconstitucional. Assim, o magistrado decidiu que o mototaxista poderia trabalhar como tal, desde que se submetesse às exigências 
legais. Ressaltou, ainda, que o transporte de pessoas por motocicletas envolve risco infinitamente superior àquele feito por carros, do que se extrai a necessidade de maior rigor administrativo na regulamentação da profissão e um efetivo e legítimo exercício do poder de polícia.

Desse modo, em decisão de primeiro grau, entendeu o magistrado que a ausência de antecedentes criminais estaria longe de ser ilegal, frisando-se que, ainda que o cidadão os possua, pode, com o tempo, readquirir a primariedade, tornando-se apto a trabalhar como mototaxista. A defensoria então apelou da decisão alegando a inconstitucionalidade da Lei municipal 8.822 e requerendo a reforma da sentença para atender a demanda dos requerentes de licença para mototaxistas. Em acórdão, a decisão foi confirmada e foi mantida a improcedência do pedido, afirmando o Tribunal, mais uma vez que é "prerrogativa do município organizar e prestar, diretamente ou sob concessão ou permissão, os serviços públicos de interesse local, inclusive de transporte de passageiros (CF, art. 30, V), podendo, por lei, interditar a participação a quem, pela natureza dos antecedentes criminais, possa representar perigo para os usuários do serviço".

Em relação à constitucionalidade da Lei, o acórdão deixou claro que "a legislação municipal impugnada não afronta a Constituição Federal, pois cuidou de regulamentar o serviço de transporte de passageiros por motocicletas, o que diz respeito a assunto de interesse local, segundo "a competência conferida pelo artigo 30, incisos I, II e V, da Constituição Federal". Com a improcedência, foi oposto Recurso Especial e Recurso Extraordinário. Os fundamentos do Recurso Especial foram alíneas "a" e "c" do inciso III do artigo 105 da Constituição da República, sob alegada violação aos seguintes artigos de lei: $1^{\circ}$ e $2^{0}$ da Lei Federal n. 12.009/2009, Lei Federal n. 9.503/1997 e $1^{\text {o }}$ e 3ํㅡ, I da Lei Municipal n. 8.222/2002 bem como divergência jurisprudencial. Este recurso foi inadmitido pelo juiz presidente com a alegação de que o recurso não cumpriu o exposto no artigo 1.029, parágrafo primeiro do CPC sob fundamento na Súmula 7 do STJ. Quanto ao Recurso Extraordinário, também foi inadmitido por ausência de repercussão geral. A decisão foi agravada e o STF se pronunciou, tendo mantido o agravo desprovido, como se mostra a seguir: 
RECURSO EXTRAORDINÁRIO COM AGRAVO 1.142.049 (887)

ORIGEM : AREsp - 00224613820108260576 - TRIBUNAL DE JUSTIÇA DO ESTADO DE SÃO PAULO

PROCED. : SÃO PAULO

RELATOR :MIN. LUIZ FUX

RECTE.(S) : DEFENSORIA PÚBLICA DO ESTADO DE SÃO PAULO PROC.(A/S)(ES) : DEFENSOR PÚBLICO-GERAL DO ESTADO DE SÃO PAULO

RECDO.(A/S) : MUNICIPIO DE SÃO JOSE DO RIO PRETO

PROC.(A/S)(ES) : PROCURADOR-GERAL DO MUNICÍPIO DE SÃO JOSÉ DO RIO PRETO

RECURSO EXTRAORDINÁRIO COM AGRAVO. CONSTITUCIONAL. AÇÃO CIVIL PÚBLICA. LICENÇA PARA MOTOTAXISTAS. AUSÊNCIA DE ANTECEDENTES CRIMINAIS. LEI 8.822/2002 DO MUNICÍPIO DE SÃO JOSÉ DO RIO PRETO - SP. UTILIZAÇÃO DE AÇÃO CIVIL PÚBLICA COMO SUCEDÂNEO DE AÇÃO DIRETA DE INCONSTITUCIONALIDADE. IMPOSSIBILIDADE. PRECEDENTES. AGRAVO INTERPOSTO SOB A ÉGIDE DO NOVO CÓDIGO DE PROCESSO CIVIL. AUSÊNCIA DE CONDENAÇÃO EM HONORÁRIOS ADVOCATÍCIOS NO JUÍZO RECORRIDO. IMPOSSIBILIDADE DE MAJORAÇÃO NESTA SEDE RECURSAL. ARTIGO 85, § 11, DO CPC/2015. AGRAVO DESPROVIDO.

Por todo o exposto, percebe-se uma enorme variação na jurisprudência quanto ao tema em comento neste trabalho. Por se tratar de uma temática que envolve conflito de direitos fundamentais, há de se fazer sempre uma ponderação, caso a caso, sendo extremamente difícil se estabelecer uma regra geral baseada na lógica do tudo ou 
nada. Deve-se olhar para cada caso, isto é, para cada requerente de licença de maneira isolada, analisando as situações com cautela e ponderação para se chegar ao melhor resultado.

\section{CONSIDERAÇÕES FINAIS}

O presente trabalho apresentou um estudo de caso e trouxe, para a discussão, um julgado do Superior Tribunal de Justiça para discutir sobre a concessão de licença para o exercício da profissão de mototaxista no município de São José do Rio Preto. No julgado, ficou estabelecido que a licença deve ser concedida mesmo ao condenado em sursis. Apresentou-se, ao longo deste trabalho, inúmeros argumentos prós e contra a decisão do julgado, todos muito bem fundamentados legalmente, doutrinariamente e jurisprudencialmente. De um lado, encontramos a temática da negação da concessão da licença, pautada no livre exercício da Administração Pública Municipal que atua autorizada pela própria Constituição Federal, como se nota expressamente no artigo 30, incisos I e II. Cita-se, também, a própria Lei Federal 12.009/2009, que corrobora com o referido diploma municipal de maneira ainda mais severa ao exigir, em seu artigo 2, parágrafo único, certidões criminais negativas para a concessão de licença.

Fala-se, ainda, na Supremacia do interesse público sobre o privado como fundamento desta posição que é contrária ao julgamento em estudo. Este princípio, que é um dos corolários da Administração Pública, traz a ideia de que havendo conflito entre interesses públicos e privados, os primeiros devem prevalecer em razão do próprio Regime Jurídico da Administração que a coloca em posição diferenciada dos particulares com prerrogativas e sujeições. Trazendo este conceito para a ótica do caso estudado, o interesse da Administração Pública teria mais relevância do que do particular que requer a licença e não preenche os requisitos exigidos na Lei. Este foi o entendimento de inúmeros julgados de diferentes Tribunais de Justiça e foi, inclusive, o entendimento da Juíza de primeiro grau que proferiu a primeira decisão sobre o caso. 
Por outro lado, corrobora com o posicionamento do julgado outros princípios consagrados e encontrados na Constituição Federal. Fala-se primeiramente e de forma mais importante na Dignidade da Pessoa Humana, que, como visto anteriormente, é o princípio basilar do Estado Democrático de Direito. Todo o ordenamento jurídico deve ser interpretado à luz da Dignidade da Pessoa Humana. Traz à baila fundamentos e objetivos da República Federativa do Brasil, tal como a valorização social do trabalho, a construção de uma sociedade livre, justa e solidária e a erradicação da pobreza e marginalização com a diminuição das desigualdades sociais. Todos fundamentados nos artigos $1^{\circ}$ e $3^{\circ}$ da Constituição e explorados e citados ao longo deste trabalho. Explanados os dois lados, cabe a opinião crítica da autora deste estudo.

Entendo que por mais que deva haver ponderação de valores constitucionais conflitantes, onde, de um lado, encontra-se a discricionariedade da Administração, pautada na Legalidade de executar seus atos visando a segurança pública dos habitantes do município, ao se confrontar com a dignidade do indivíduo que requer a licença, este primeiro argumento cai por terra. Não me parece equilibrado comparar a soberania da Administração com a possibilidade de recuperarão e ressocialização de um condenado que não apresente alta periculosidade. Enxergo como corretíssima a decisão do STJ em conceder a licença no caso em questão e mais coerente ainda foi a lição trazida pelo julgado de que o próprio Estado que exige que o indivíduo exerça um trabalho, nega a sua licença para tal. É incoerente e até um pouco preconceituoso. Ademais, a solicitação de certidões criminais ofende o princípio da presunção da inocência, como foi fundamentado em algumas jurisprudências trazidas à baila.

\section{REFERÊNCIAS}

BRASIL. Constituição (1988). Constituição da República Federativa do Brasil. Brasília: Senado, 1988. 168p.

BRASIL. Decreto-Lei no 2.848, de 7 de dezembro de 1940.Código Penal. Disponível em: http://www.planalto.gov.br/ccivil_03/decreto-lei/Del2848compilado.htm. Acesso em: 21 fev. 2019. 
BRASIL. Lei 12009, de 29 de julho de 2009. Regulamenta o exercício das atividades dos profissionais em transporte de passageiros, "mototaxista", em entrega de mercadorias e em serviço comunitário de rua, e "motoboy", com o uso de motocicleta, altera a Lei no 9.503, de 23 de setembro de 1997, para dispor sobre regras de segurança dos serviços de transporte remunerado de mercadorias em motocicletas e motonetas - moto-frete -, estabelece regras gerais para a regulação deste serviço e dá outras providências. Disponível em: http://www.planalto.gov.br/ccivil_03/_Ato2007-2010/2009/Lei/L12009.htm. Acesso em: 21 fev. 2019.

BRASIL. Lei 13.105, de 16 de março de 2015. Código de Processo Civil. Disponível em: http://www.planalto.gov.br/ccivil_03/_Ato2015-2018/2015/Lei/L13105.htm. Acesso em: 21 fev. 2019.

BRASIL. Lei 7210, de 11 de julho de 1984. Institui a Lei de Execução Penal. Disponível em: http://www.planalto.gov.br/ccivil_03/Leis/L7210.htm. Acesso em: 21 fev. 2019.

BRASIL. Lei 9503, de 23 de setembro de 1997.Código de Trânsito Brasileiro. Disponível em: http://www.planalto.gov.br/ccivil_03/LEIS/L9503.htm. Acesso em: 21 fev. 2019.

BRASIL. Superior Tribunal de Justiça. Agravo em Recurso Especial $n^{\circ}$ 495725/SP. Relator: Ministro Napoleão Nunes Maia Filho - Primeira Turma. Diário de Justiça Eletrônico, Brasília, 23 mar 2018. Disponível em: https://stj.jusbrasil.com.br/jurisprudencia/565517477/ agravo-em-recurso-especialaresp-495725-sp-2014-0066962-4. Acesso em: 21 fev. 2019.

BRASIL. Supremo Tribunal Federal. Habeas-Corpus n 95464, Relator: Min. CELSO DE MELLO, Segunda Turma, julgado em 03/02/2009, DJe-048 DIVULG 12-03-2009 PUBLIC 13-03-2009 EMENT VOL-02352-03 PP-00466.

BRASIL. Supremo Tribunal Federal. Recurso Extraordinário com Agravo $\mathbf{n}^{\circ}$ 1.142.049 (887). Relator: Ministro Luiz Fux - Primeira Turma. Diário de Justiça 
Eletrônico, Brasília, 10 de agosto de 2018. Disponível em: https://www.jusbrasil.com.br/diarios/documentos/612421528/andamento-doprocesso-n-1142049-recurso-extraordinario-agravo-14-08-2018-do-stf. Acesso em: 21 fev. 2019.

DIÁRIO DE JUSTIÇA DO ESTADO DE SÃO PAULO. Página 1375 da Judicial - 1aㅗ Instância - Interior - Parte III do Diário de Justiça do Estado de São Paulo (DJSP) de 21 de Janeiro de 2011. 2011. Disponível em: https://www.jusbrasil.com.br/diarios/24311853/pg-1375-judicial-1-instancia-interiorparte-iii-diario-de-justica-do-estado-de-sao-paulo-djsp-de-21-01-2011. Acesso em: 06 mar. 2020.

LENZA, P. Direito Constitucional Esquematizado. 15a . ed. São Paulo: Saraiva, 2011.

MASSON, N. Manual de Direito Constitucional. 6․․ Ed. Salvador: Editora Juspodium,2018.

MATO GROSSO. Tribunal de Justiça. Agravo $\mathbf{n}^{\circ} \mathbf{0 1 5 5 6 3 4 8 4 2 0 1 5 8 1 1 0 0 0 0}$ 155634/2015, Relatora: Desembargadora Maria Erostides Kneip Baranjal, Terceira Câmara Civil, julgado em 01/12/2015. Data de Publicação: 15/12/2015.

MINAS GERAIS. Tribunal de Justiça. Apelação Cível $n^{\circ}$ 10000170535058001, Relatora: Desembargadora Áurea Brasil, 5a Câmara Civil, julgado em 14/11/2017. Data de Publicação: 24/11/2017.

NOVELINO, Marcelo. Direito Constitucional. São Paulo: Editora Método, 2010.

PADILHA, R. Direito Constitucional. 5ª ed. São Paulo: Editora Método, 2018

SÃO JOSÉ DO RIO PRETO. Lei Municipal 8.822 de 18 de dezembro de 2002. Disciplina a atividade de mototaxista. Disponível em: https://leismunicipais.com.br/a/sp/s/sao-jose-do-rio-preto/leiordinaria/2002/882/8822/lei-ordinaria-n-8822-2002-da-nova-disciplina-a-atividade- 
relativa-ao-servicos-de-transporte-individual-de-passageiros-em-motocicletasmediante-aluguel-moto-taxi-e-da-outras-providencias. Acesso em: 21 fev. 2019.

SÃO JOSÉ DO RIO PRETO. Lei Municipal 10.835 de 24 de novembro de 2010. Disciplina a atividade relativa aos serviços de transporte individual de passageiros em motocicletas mediante aluguel - moto táxi. Disponível em: https://leismunicipais.com.br/a/sp/s/sao-jose-do-rio-preto/leiordinaria/2010/1083/10835/lei-ordinaria-n-10835-2010-altera-dispositivo-da-lei-n8822-de-18-de-dezembro-de-2002-que-disciplina-a-atividade-relativa-aos-servicosde-transporte-individual-de-passageiros-em-motocicletas-mediante-aluguel-mototaxi. Acesso em: 21 fev. 2019.

SARLET, I. W. A eficácia dos direitos fundamentais. $2^{2}$. ed. Porto Alegre: Livraria do Advogado, 2001.

SARLET, I. W. Dignidade da pessoa humana e direitos fundamentais na Constituição Federal de 1988. 9ª ed. Porto Alegre: Livraria do Advogado, 2012.

UBERABA. Lei Municipal 11.162 de 10 de Maio de 2011. Regulamenta o exercício das atividades dos profissionais em transporte de passageiros "mototaxista", serviço comunitário de rua "motoboy" e transporte de mercadorias "moto-frete", e contém outras disposições. Disponível em: https://leismunicipais.com.br/a/mg/u/uberaba/lei-ordinaria / 2011/1116/ 11162/leiordinaria-n-11162-2011-regulamenta-o-exercicio-das-atividades-dos-profissionaisem-transporte-de-passageiros-mototaxista-servico-comunitario-de-rua-motoboy-etransporte-de-mercadorias-moto-frete-e-contem-outras-disposicoes. Acesso em: 21 fev. 2019.

Enviado: Fevereiro, 2020.

Aprovado: Março, 2020. 